\title{
Symbolical Content for Regulatory Bases of Intonation Culture
}

\author{
Oksana V. Rtishcheva and Irina A. Shikaleva* \\ Kemerovo State Institute of Culture and the Arts \\ 17 Voroshilova Str., Kemerovo, 650029, Russia
}

Received 08.05.2017, received in revised form 17.09.2018, accepted 01.10.2018

\begin{abstract}
The authors consider intonation culture in the aspect of identifying the regulatory principles of communication processes. The study also pays attention on the symbolical content of intonation culture providing coordination for functional model of communication with opening the valuable determinants promoting expression of cultural identification. Moreover the study defines the genesis for implementing the symbolical contents of intonation culture through a prism of developing musical and language consciousness. Therefore music, being the highest form showing intonation culture, actualizes the intoning consciousness which serves as a peculiar bridge between the biological and symbolical information expressed in experiences of the person.

But also the study considers substantial features for functioning intonation culture through appealing the characteristic of its symbolical values and in this way it is necessary to analyze the culturological ideas of L. White on the symbolical content of ways for implementing the regulatory bases in culture. So defining the sense for culture substantial filling, L. White enters the term "simbling" for designating symbolical expression of the phenomena class having extra somatic characteristics. In this way the key ability of a person is to discover the symbolical meanings forming the substantial field of culture. Therefore development of intonation culture is considered within the ability of the symbolization providing a possibility for transferring values according to the linear principle of cultural development. Thus, intonation culture works as the special system of cultural continuity promoting, on the one hand, cumulating valuable experience, and on the other hand, broadening sensual space of valuable experiences.
\end{abstract}

Keywords: communication, intonation culture, musical reality, value, symbol, sign.

Research area: theory and history of culture.

Citation: Rtischeva, O.V., Shikaleva, I.A. (2018). Symbolical content for regulatory bases of intonation culture. J. Sib. Fed. Univ. Humanit. soc. sci., 12(7), 1282-1294. DOI: $10.17516 / 1997-1370-0334$.

(c) Siberian Federal University. All rights reserved

* Corresponding author E-mail address: ortishheva@mail.ru

This work is licensed under a Creative Commons Attribution-NonCommercial 4.0 International License (CC BY-NC 4.0). 


\section{Introduction}

Modern culture is characterized by conceptualization eclecticism; the appeal to utilitarian values becomes the regulatory basis of communication processes. It is caused by a number of factors connected with domination of the functional role model of communication directed to establish accurate, clear and concrete forms of communication. This fact is actualized due to existence of a big flow of information which isn't demanding the reflexive relation; and such characteristics of the modern personality as pragmatism, orientation to usefulness of a thought and the action getting into the sphere of culture as its immanent properties become very attractive.

The similar situation defines the importance of a rational goal-setting in organizing communication processes. Orienting the participants of communication on practical solution of common problems can be considered as an axiomatic condition for communication and without them ensuring regulation according to the following positions is impossible: a problem-setting — a goal-setting — an instrument-setting. The similar logic was offered still by Aristotle considering communication as the process connected with a goal-setting, including a message source, the message, the way of its transfer and the recipient.

Really, regulatory relations of communication process subjects are connected with forming the activity relying on the existing knowledge about the direction and the forms of communicative activity; and also which settings of the program have to be the basis for achieving coordinated actions at realizing the purpose, general for the communication act. The regulatory bases of communication processes in this case come down to the organization of interaction between the participants of communication; in which transferring information is connected with the organization of successful and coordinated interaction between the partners in a certain context. The program of goal-setting providing regulatory functions of the process for forming and exchanging information becomes a communication dominant in this case and this fact actualizes the importance of functional contents of any statement.

However in this situation there is a loss of symbolical characteristics of communication that depreciates its valuable contents connected with expression of cultural identification. Considering this problem, O. A. Grishina rightly notes: "Live speech usually expresses immeasurably more than it denotes. The true, concrete meaning is revealed not only through the meanings and meaning of words, but, to a greater extent, through emotional and expressive means (intonation, voice modulation, rhythmic and melodic component, pause, and etc.)" (Grishina, 2013: 32). Restricting the opportunities for communication 
connected with losing emotional participation in communication process the nature of mutual understanding between people is transformed and it begins to be defined by the unilateral solution of private tasks. Similar change of vital reference points leads to the irreparable losses promoting violation of the confidential relations, loss of the responsible position demanding the appeal to steady valuable reference points.

\section{Genesis for symbolic bases of intonation culture}

"Live speech", which reveals the true content of communicative processes, is supported by appealing to the emotional background, being fixed in a certain intonation. Its consideration in the aspect of forming the regulatory principles for the development of culture contributes to identifying value orientations ensuring the consolidation of the symbolic experience of the most significant forms of social and significant activity of people. These attitudes are realized in appealing to communication, conditioned by the specifics of its intonation forms.

The dominant value of intonation in relation to forming articulated speech, capable for expressing symbolic meanings is determined by its early origin, which is noted by many anthropologists (E. Condillac, E. Tylor, L. G. Morgan, A. Wallace, W. Wundt, etc.) (Sher, 2004). For example, A. V. Toropova in her work argues that intonation as an element and a way for symbolizing the experience of meaning has a clearly expressed relation to "the essential aspects of forming natural speech, its communicative orientation, the processes of perception, thinking, understanding and communication" (Toropova, 2014: 72). Considering intonation / intoning is more accurate than speech, reflects the intrapsychic manifestations of personality, acting as a kind of "echo-location" of the ongoing mental processes, A. V. Toropova comes to the idea that intonation, accompanying the formation of emotional, cognitive sphere, "is the form of the primary psychic activity of the personality that contributes developing the sign-intoning function of consciousness" (Toropova, 2014: 75).

To date, the independent status of intonation activity is considered in relation to the structure of musical and linguistic consciousness; therefore the genesis of intoning forms is determined by the levels of musical and symbolic reality. So A. V. Toropova distinguishes three basic levels for conceptualization of intonation in musical language:

- general (archetypal) level is fixed in the universals of musical languages;

- special (cultural and linguistic) level is fixed in cultural and conventional language stereotypes of intoning experiences (ethnic and cultural intonation vocabulary of speech, gesture and musical intonation); 
- sign level is denoted in established intonation and semiotic formulas as signs of culture, appearing in linguistic branches of consciousness and marking its multi-unit identity — speech, plastic, musical (intoning) (Toropova, 2014: 79-80).

These levels of forming musical and symbolic reality characterize intonation as an indicator or state of tone (intoning) tension, defining "verbal speech" and "musical speech" and serves as an impulse for forming and developing intonation culture (Asaf'ev, 1971: 355).

Thereby, B. V. Asafiev argues: "It is possible, for example, that intonation as a phenomenon of understanding the timbre (the quality by which people distinguish the voice of the mother, the child, the beloved woman, or the native speech, regardless of the content of the spoken sounds and regardless of feelings and emotions) had the greatest impact on forming and consolidating certain constants in the mind - constant sound connections, which gave birth to a melos - a meaningful and melodious speech; and strong sound connections, i. e., intervals, were distilled already from it. In this quality (understanding the timbre) intonation acts both behind speech, and behind music, preceding them" (Asaf'ev, 1971: 240).

Characterized by an appeal to symbolic meanings, the intonation culture formed its content, being closely associated with speech and music, that both oral-poetic and musical folklore vividly demonstrate (the evolution of the word was in constant correspondence with the development of musical art). Asaf'ev B.V. emphasizes that intonation transmitted oral tradition is characterized by a holistic view of the world, but in the future this integrity was violated: "The growth of musical life, which provided the progress of European music, created this contradiction" (Asaf'ev, 1971: 300). Thus, the researcher comes to the conclusion that developing intonation culture is associated with an intensive growth of musical art and an understanding of its meaningful significance, which provoked the existence of "a long and difficult struggle for the place, conjugation and meaning of the sounding for each interval in the mode system in which the shift scales is a consequence of social selection, carried out by the ear of a social person" (Asaf'ev, 1971: 241-364). Syncretic ambiguity of content, inherent in words-images-concepts in the early stage of language development, initially perceived by people through intonation utterance in the form of music, gesture, word, image, i. e. the sign of reality, eventually differentiated with due regard for the subtlest nuances of intonation, which subsequently led to forming various types of intonation art.

Until the moment of differentiation, not one century of a long and difficult struggle for approving the independent status of each interval, each intonation complex and 
each art passed. Considering intonation in the context of developing musical culture, B. V. Asaf'ev distinguishes the following links of its establishing:

- the first link is the individualization of human thoughts and feelings. Here the musical tone is mainly formed its base in singing, breathing and in melody, its appearance indicates the age-old effort of human thought, led it to freedom and selfdevelopment: "Neither in the field of poetry, either in the field of music, we would not have reached such heights in the cultural history of humanity if in primitive society, together with developing arm tactility existed sensitive and delicate intonation speech rather say intonation language" (Asaf'ev, 1971: 240);

- the second link for intonation development, according to B. V. Asaf'ev, is the melodic beginning out of vocalism, when the instrumental culture takes possession of the melody and a concerting and then quartet style appears as the highest expression of music-thought (Asaf'ev, 1971: 322). At this stage of development, the musical intonation specifically widened and enriched human relations with the world, giving them a valuable and expressive character, most vividly characterizing the intonation side of culture;

- the third link for forming intonation culture is the theater development (from pantomime to ballet). The musical and intonation reformation in Italy $\left(16^{\text {th }}-17^{\text {th }}\right.$ centuries) promotes this process, as B. V. Asaf'ev proves, and led to the independent identification, formation and development of the opera. The spread of opera art can be explained by "establishing intonation culture of humanity as a communication of people", expressed by "the fullness of musical intonation expressiveness, the rhythm evolution, the word, the musical sound achieved in images of melody" (Asaf'ev, 1971: 322).

Music, being the highest form for showing intonation culture and having a unique "philosophical content, dialectical character of development, generality of images, dynamism of intonation nature, symbolism, directness of emotional impact, and ability to model human emotions", began to reproduce subtly the phenomena associated with the cultivation of key values which are conceptualized, taken root and turned to a higher artistic quality, promoting growth of spiritual and aesthetic, organizational and creative, and informative forms of intonation culture" (Smotrova, 2014: 12). As a result of active artistic and creative activity, musical thought was a component of intellectual culture; the ideological purposefulness of the thinker-composer led to the necessity of reproducing meanings at the highest professional level in art. Noting the peculiarities of this process, T. S. Kniazeva writes: "In art, intonation becomes the 
main carrier of artistic information and artistic meaning ... It is an" encyclopedia of world feeling", the range of which extends from "the simplest emotions to holistic attitude and world outlook, and forms an intonation field of culture" (Kniazev, 2006). When interacting with music, the experience symbolization, performed by a person, turns on an intoning consciousness that serves as a kind of bridge between biological and symbolic information, providing the development of the communicative space, communication, culture, society, traditions, life models (Solopanova, 2011). Intoning consciousness acts as a kind of individual filter through which the person perceives and sifts reality, grinds personal meanings of existence and reaching in its development to new meanings.

Highlighting the intoning consciousness as a general sign and symbolic function of the psyche, A. V. Toropov proves that "in the phenomenon of musical consciousness and in the nature of the musical symbol, there is a syncretic unity with other intonamas of consciousness - movement, visual signs, verbal speech, which form a single sign reality, disintegrating in culture into separate forms of intonation: plastic, static, sound, and fixed in the corresponding language system" (Toropova, 2014: 73). That is, to perceive and not to lose meanings, symbols, images of musical and plastic traditions, there should be a constant activation of the intoning consciousness. "In traditional cultures, the calendar and liturgical cycles contributed to this, including people into constantly confirmed identity through intonation ritual, reproducing a certain sign and symbolic reality" (Toropova, 2014: 73). Thus, the logic development of intonation culture testifies to the necessity of actualizing various forms of its symbolic meaning, which is possible while retaining links with primary symbolic meanings providing the preservation of its living intentions that promote the organic regulation for communication processes. According to G. M. Press, for full-fledged, high-quality intonation, emotional and mental participation is necessary, it is possible due to the ability of the brain to provide a sound expression of spiritual, vital, moral, intellectual, professional experience, making intonation convincing, meaningful and emotional; according to the traditional demands, style, author's intention, in other words, embodies cultural meanings in sounding (Press, 2008).

\section{Symbolical content of intonation culture in the context of culturological ideas of $\mathrm{L}$. White}

Considering substantial features of functioning intonation culture it is important to study the characteristic of its symbolical values that causes the review of the 
culturological ideas of $\mathrm{L}$. White on the symbolical content of ways for implementing the regulatory bases in culture. In the preface to one of his fundamental works "The science of culture" (1949) American researcher writes: "It is clear that culture is not just reflex reaction to the environment, not simple and direct show of human nature. There was an understanding that culture is a continuum, a stream of events, freely current through time from one generation to another, and in the horizontal direction -from one race or environment to other race or environment" (White, 2004: 8). Therefore by analogy with the physical form of the reality determined by the corresponding minimum unit (atom, or a proton and etc.), biological, characterized by the cell, L. White equips culture with the independent lines connected with functioning symbols in the following relations:

- time - is a history of culture or history of civilization;

- space-time - is a cultural evolution;

- space - is a repeating of cultural and determined processes for human society (White, 2004: 30).

In these relations the American researcher excludes considering culture depending on the person, focusing attention on its independent being. Criticizing modern anthropological concepts in which culture is identified with psychological or social reality, L. White approves necessity for defining the independent status of culture regardless of human will: "Many our the best minds still argue as if destinies of a civilization were in the hands of a person and they would be fated to fail or find rescue depending on his own will and choice ... And our culture develops and changes according to own laws. As soon as we outgrow our primitive and childish idea of our domination and we will begin to study the nature of culture in which we live, our idea of ourselves will become probably less flatter, but we will learn to organize our life more rationally and effectively" (White, 2004: 127). Actually in these ideas L. White rejects anthropocentric prerequisites of culture according to the principle of determinism. And according to these prerequisites the person is the creator of culture, and any of its elements is the result of his creative act (Astakhov, Shikaleva, 2014).

However the author doesn't exclude to consider the system of relationship between the person and culture, and connects it with functioning of symbols. Defining the sense of substantial filling of culture, L. White enters the term "simbling" for designation of symbolical expression for the phenomena class of extra somatic character. According to it the author notes that "the culture makes a supra biological or extra somatic class of events, the process of sui generis" (White, 2004: 27). In this case key ability of 
the person is a discovery of the symbolical meanings forming the substantial field of culture.

According to the remark of L. A. Kalantarian, the American scientist proves the necessity for differentiating the approaches to realize this ability of symbolization. The first is connected with symbolization in relationship with a somatic context that reflects the "human behavior" studied by psychology; the second approach is defined by an extra somatic context that is expressed by the appeal to the "cultural lines" studied by culturology (Kalantarian, 2012). In turn, N. I. Romakh and T. Belenikina prove that despite distinction of the existing approaches, the psychology and cultural science in L. White's concept supplement each other. These sciences are equally important for realizing the fact that the person is characterized from a position of his uniqueness, at the same time descriptive approach studying relations between the person and culture is supplemented with symbolical that forms novelty of L. White's ideas (Romakh, Belenikina, 2009).

Thus the culturological analysis of the phenomena class of extra somatic character is inevitably caused by considering the ability of symbolization providing dynamics for developing intonation culture. In this way I. V. Levitskaia notes that in culturological generalizations of L. White, the questions of culture and homo sapiens origin are considered not through the axiomatic ideas on creating labor instruments as leading factor for the person formation, but through appearing the ability of symbolization as the main means of activity providing formation of cumulative and continuous experience of life through the appeal to traditions (Levitskaia, 2011: 7). These ideas were continuation of reasoning of E. Kassirer on appearing symbols as the main condition for the person development. However L. White according to the positivism concept focuses attention on the effective content of symbols. "Only people use symbols and any other living being doesn't. The organism has ability to symbolize, or has not; there are no intermediate stages here" (White, 2004: 37). Therefore consciousness of the person differs not in a measure and degree, but in fundamental feature of symbolization.

In this way there is a question of mechanisms for realizing the symbolical nature of the person's consciousness which L. White connects with the special event action: "The category (or an order) of cultural phenomena is formed from those events which depend on person's ability to use symbols. These events are the ideas, beliefs, languages, tools, devices, customs, feelings and institutions which make a civilization (or culture if to use the anthropological term) of any nation despite of the time, the place and the development level" (White, 2004: 27). The language has a special 
position in this list of phenomena; the author considers it as the condition for culture existence opening a possibility for symbolical communication. L. White writes: "Thus, without symbolical communication we wouldn't have culture. In the word there was a beginning of culture - and also its continuation" (White, 2004: 46). And if the word gave a birth to culture, so a possibility for language communication is appearing ability of symbolization. According to the above mentioned it is possible to note that the intonation accompanying verbal communication is also symbolical expression.

Considering the example when the Spanish conquerors met Aztecs for the first time, and they didn't know common language, the researcher writes that "both Spaniards and Aztecs could find meanings of other party and estimate its values. But it was not made sensory. Everyone could get into the world of another only due to that ability for which there is no the best name, than symbol" (White, 2004: 38). This situation for the author is the evidence that the differentiation in the word of its sensory and perceived physical form and meaning becomes a condition of its existence as a symbol which should be distinguished from the sign. And intonation in this way should be understood as a possibility for transforming the word to a symbol. In case of sensual realizing the word when its meaning is identified with the physical form the word functions as a sign.

On the example of a ratio of a voice stimulus and reaction $\mathrm{L}$. White characterizes the mechanism of acting a sign: "We see in sign behavior that while establishing connection between stimulus and reaction the nature of reaction isn't determined with the properties which stimulus has internally. However after connection is already established, the meaning of stimulus becomes such as though it was internally situated in its physical form" (White, 2004: 40). And therefore it is possible to teach any animal to execute voice commands which are perceived as stimulus for the corresponding reaction. "The person differs from a dog — and from all other living beings — the fact that he can play and really plays an active role in defining the meaning of the voice stimulus, but the dog can't do it, - L. White writes. - The dog doesn't play and can't play an active role in defining the meaning of a voice stimulus" (White, 2004: 40-41). Therefore, distinctive feature of the person is that he can accept, and also transfer new values having symbolical character due to a language intoning.

Effective character of the language intoning realizing ability of symbolization is shown in the articulated speech. And the articulated speech discovers new meanings defining cultural development. "The articulated speech is a form of symbolical expression, - L. White proves. - Eliminate the speech from culture - and what then will remain?" (White, 2004: 45). And in this case, the researcher argues, there 
is impossible a social organization, political, economic, church and military; "any etiquette or ethics; any laws; any science, theology or literature; any games or music, except as at the level of a monkey. Without the articulated speech ceremonies and ceremonial accessories wouldn't make sense" (White, 2004: 45-46). The key moment in the author's ideas on the articulated speech is its progressive activity that provides symbolical behavior of the person.

According to these symbolical aims focused on the person development, in the practice of nonverbal communication finding cultural meanings and values is also possible. As an example L. White describes a case with E. Keller who became the blind and deaf person as a result of a disease at early age. Her development was possible overcoming direct link of written designation of the word and its sensual feeling and discovering the fact that "everything has the name". The researcher describes a situation of discovering the word not only as a sign, but also as a symbol: "However now these words are already something bigger, than just signs what they are for a dog and what they were for Elaine. They were symbols. Elaine at last groped and turned that key which for the first time opened for her an entrance to the new Universe - to the world of human beings" (White, 2004: 50).

Thus the author focuses attention that distinctions between verbal and nonverbal communication are removed with the aims on progressiveness for the person development capable for symbolization. And in this case the researcher's ideas on the articulated speech should be considered as the instruction on progressive effectiveness of the language statement: "The articulated speech means exchange of thoughts; exchange of thoughts means preservation or tradition, and preservation means accumulation and progress" (White, 2004: 51). In this logical chain characterizing the importance of the articulated speech, L. White connects together two vectors of action: preservation and purposeful development. Similar conclusions reflect aims of the author for considering dynamics of culture as evolutionary development which chronological sequence is defined with progressive transformation of cultural forms. And in this context the content of intonation culture is defined with specifics of the symbolization providing a possibility for transferring values according to the linear principle of cultural development.

\section{Conclusion}

Thus, intonation culture works as a special system of cultural continuity promoting, on the one hand, to accumulate a valuable experience, and on the other 
hand, to expand sensual environment of valuable experiences. As a result of this fluctuation the borders between values of the past and the present are disappeared that promotes multidimensional self-identification of the personality: "Internal making of the personality in the process of intoning happens through a reflection and assignment of patrimonial experiences (even absent in the life of person, and transferred to him in an image and a symbol)" (Toropova, 2014: 73-76). In the course of its formation, intonation culture becomes a peculiar tank of standards, signs, symbols which is replenished by means of people's ability for symbolization.

When realizing that "the area of intonations as semantic sound identification is boundless" its presence at all stages of cultural development is indisputable, we come to a conclusion that intonation is a way for implementing symbolical meanings therefore intonation culture has the regulatory bases of a complex for valuable reference points. It is characterized by specifics of symbolical communication between the person and the world accumulating the figurative and semantic content of communication in different types and forms of the activity showing spiritual property of the personality (culture). In turn the phenomenon of intoning as a general feature of intonation culture is shown in ability of symbolization the result of which is education, accumulation, transfer of cultural meanings having something in common with the nature of functioning simvolats (L. White).

\section{References}

Asaf'ev, B.V. (1971). Muzykal'naia forma kak protsess [Musical form as a process]. Leningrad, $378 \mathrm{p}$.

Astakhov,O. Iu.,Shikaleva,I.A.(2014).Printsipy determinzmavkul'turologicheskoi metodologii L. Whyte [The principles of determinism in culturological methodology of L. Whyte]. In Vestnik Kemerovskogo gosudarstvennogo universiteta kul'tury I iskusstv [Bulletin of Kemerovo University of Culture and Arts], 2 (27), 62-66.

Grishina, O.A. (2013). Russkaia intonologia [Russian intonology]. Krasnoiarsk, 136 p. Available at: http://elib.kspu.ru/document/10596 (accessed 20 April 2017).

Kalantarian, L.A. (2012). Funadamental'nye problem sovremennoi kul'turnoi antropologii [Fundamental issues of modern cultural antropology]. In Kul'tura kak obekt filosofskogo osmyslenia [Culture as an object for philosophical realizing], 2(5), $110-113$.

Kniazeva, T.S. (2006). Intonatsionnaia osnova khudozhestvennoi vyrazitel; nosti lichnosti [Intonation base for art expression of the person]. In Razvitie lichnosti 
[Development of Personality], 1, 84-94, available at: http://rl-online.ru/articles/ rl01_06/516.html

Levitskaia, I.V. (2011). Kotseptsia kul'turologii L. Whyte: Pro et contra [Culturology concept of L Whyte: Pro et contra]. In Vestnik Samarskogo Gosudarstvennogo Universiteta [Bulletin of Samara State University], 1(82), 5-10.

Press, G.M. (2008). Intonirovanie kak universal'nyi mekhanizm smysloobrazovania I smysloproiavlenia $v$ kul'ture: avtoreferat dissertatsii [Intoning as a universal mechanism for sense forming and sense processing in culture: abstract of the thesis]. Biisk, 16 p.

Romakh, Kh.I., Belenikina, T. (2009). Stanovlenie kul'turologii na Zapade [Establishing culturology in the West]. In Analitika Kul'turologii [Analytics of Culturology], 2 (14), available at: http://www.analiculturolog.ru/journal/archive/ item/391-article_19-6.html (accessed: 4 August 2016).

Sher, Ia.A. (2004). Proiskhozhdenie znakovogo povedenia [Origin of sign behavior]. Moscow, 249 p.

Smotrova, E.V. (2014) Integrativnyi podkhod $k$ formirovaniu u ml; adshikh shkol'nikov tselostnogo predstavlenia ob iskusstve (na material urokov muzyki $v$ shkole): avtoreferat dissertatsii [Integrative approach to form complete idea of art for younger school students (on material of lessons of music at school): abstract of the thesis]. Moscow, $28 \mathrm{p}$.

Solopanova, O. Iu. (2011) Fenomen pedagogicheskogo intonirovania v organizatsii obrazovatel'nogo protsessa: avtoreferat dissertatsii [Phenomenon of a pedagogical intoning in the organization of educational process: abstract of the thesis]. Krasnodar, $56 \mathrm{p}$.

Toropova, A.V. (2014) Fenomen intonirovania kak antropologicheski orientir sokhranenia i vosIroizvodstva oblika cheloveka opredelennoi kul'tury [Intoning phenomenon as anthropological reference point of preserving and reproducing the person in a certain culture]. In Vestnik Pravoslavnogo Sviato-Tikhonovskogo gumanitarnogo universiteta [Bulletin of Pravoslavnyi Sviato-Tikhonovski Humanities University], 3 (34), 72-84.

White, L. (2004). Izbrannoe. Nauka o kul'ture [The Science of Culture]. Moscow, $960 \mathrm{p}$. 


\title{
Символическое содержание регулятивных оснований интонационной культуры
}

О. В. Ртищева, И. А. Шикалева

Кемеровский государственный институт культурь Россия, 650029, Кемерово, ул. Ворочилова, 17

\begin{abstract}
Рассматривается интонационная культура в аспекте выявления регулятивных принцииов коммуникационных процессов. Внимание акцентируется на символическом содержании интоначионной культуры, обеспечивающем согласование функииональной модели общения с открытием ценностных детерминант, способствующих выражению культурной идентификации. Определяется генезис реализации символического содержания интонационной культуры через призму развития музыкально-языкового сознания. Именно музыка, будучи высшей формой проявления интонационной культуры, актуализирует интонирующее сознание, которое служит своеобразным мостом между биологической и символической информацией, выраженной в переживаниях человека.
\end{abstract}

Рассмотрение содержательных особенностей функиионирования интонационной культуры осуществляется при обращении к характеристике ее символических значений, что определило необходимость анализа культурологических идей Л. Уайта о символическом содержании способов осуществления регулятивных оснований в культуре. Определяя смысл содержательного наполнения культуры, Л. Уайт вводит термин «simbling» для обозначения символического выражения класса явлений экстрасоматического характера. В этом случае ключевой способностью человека является открытие символических смыслов, формирующих содержательное поле культуры. Развитие интонационной культуры рассматривается в отношении к способности символизащии, обеспечивающей возможность трансляции ценностей в соответствии с линейным принципом развития культуры. Таким образом, интонационная культура действует как особая система культурной преемственности, способствующая, с одной стороны, кумуляции ценностного опыта, а с другой - стороны, расширению чувственного пространства иенностных переживаний.

Ключевые слова: коммуникация, интонационная культура, музыкальная реальность, ценность, символ, знак.

Научная специильность: 24.00.01 - теория и история культуры. 